\title{
IRRIGATION EFFICIENCIES OF SUGAR CANE YIELD UNDER DIFFERENT FURROWS LENGTHS IN UPPER EGYPT
}

\author{
El Mawla ${ }^{1}$ H. A. A., El Lithy ${ }^{2}$ A. M., HASSAN ${ }^{3}$ S. S., \\ HASSAN $^{4}$ O. D. and Mahmoud ${ }^{5}$ A. M.
}

\begin{abstract}
The research field experimental work was conducted at the farm of ElMattana Research Station of the Agricultural Research Center, Luxor Governorate, Upper Egypt during growing season 2012\&2013 in clay soil on sugarcane crop. The objective of the herein research trial are to study surface irrigation system performance through using gated pipe system technique under different furrows irrigation lengths treatments $L_{125}(125 \mathrm{~m}) L_{100}(100 \mathrm{~m}) . L_{75}(75 \mathrm{~m})$ and land slope $0.1 \%$ comparing with the traditional irrigation methods under the same condition and treatments. The consequent effects of applying such methods on advance, recession and opportunity time, total water applied, yield, water application efficiency and water use efficiency for sugar cane was considered. The Results showed that the total head losses due to friction was increased gradually until reached $8.4 \%$ of the original pumping pressure head measured. The flow variation through 18 meters apart of the gated pipe system was about $13.9 \%$. Therefore the uniformity distribution of flow through outlets along the gated pipe system was about $86.1 \%$. On the other hand pressure head variation was about $9.42 \%$. The result revealed that the traditional methods received more amounts of irrigation water than gated pipe system in the three cases of furrow lengths. The highest values water saving were achieved by using irrigation gated pipe technique with leveling by laser technique 0.1\% slope. The traditional irrigation $\left(T_{1}\right)$ gave lower water application
\end{abstract}

1. Prof. of Agric. Eng. Dept., Fac. Agric., AL-Azhar Univ., Assiut.

2. Prof. of Agric. Eng. Dept., Fac. Agric, AL-Azhar Univ., Assiut.

3. Head Res. Agri. Eng., Rese. Inst. Agric. Res. Cen., MOA, Cairo, Egypt.

4. Ass. Prof. of Agric., Ext. Dept., Fac. of Agric. AL-Azhar Univ., Assiut.

5. Ass. Tch., Agric. Eng. Dept., Fac. Agric, AL-Azhar Univ., Assiu. 
efficiency than irrigation using gated pipe system $\left(T_{2}\right)$ The maximum value of sugar cane yield was achieved in case of using irrigation gated pipe at L100 with $0.1 \%$ slope treatment. On the other hand, the minimum value of sugar cane was achieved in case of irrigation traditional method at L 75 treatment. The average values of sugar cane yield were 55 and 42 ten/fedan under gated pipe and traditional irrigation method respectively. The irrigation with gated pipe improved yield WUE for sugarcane crop under three treatments furrows lengths compared to traditional irrigation.

\section{INTRODUCTION}

Trigation water consumes about $80 \%$ of the water budget for cultivating approximately 7.1 million feddans with an annual crop area of about 12 million feddans. Now the saving of irrigation water is considered a strategically target of Egypt. Sugarcane is considered the main materials for sugar processing and it occupied the scored important economic crop and it enters in many industry productions. The total sugarcane cultivated area reached about 312 thousand feddans concentrated around sugarcane mills in middle and Upper Egypt. It is considered a highly water consuming crop in Egypt especially under the conventional irrigation method (General Administration of Agricultural Economics 2004). The applied irrigation water for sugarcane is estimated to be 12000 to more than 16000-m3/fed./year. Therefore the agricultural and irrigation Egyptian policies have been working to improve the surface irrigation system especially in the sugarcane farms in the Egyptian old valley at Upper Egypt by using developed surface irrigation systems. Abo Soliman et al. (2005) indicated that the irrigation by gated pipe achieved the highest values of yield and saved amount of irrigation water applied by $11.9 \%$. Sonbol et al. (2007) stated that the short furrows irrigation combined with $0.1 \%$ ground surface slope and dead level received the less amounts of irrigation water and also, water application efficiency increased compared to long furrows and border irrigation. The data showed that the highest values of crop and field water use efficiencies were achieved with short furrows irrigation and $0.1 \%$ ground surface slope. El Berry et al. (2006) concluded that the priority is given to use the developed surface irrigation 
systems in large areas with less field length to get the maximum benefit from: 1-Low capital investments used for execution, to cover more area. 2-Saved areas which were occupied by channels and ridges. 3-The reduction in the amount of irrigation water per Fadden, and consequently in increased saving in water losses. 4-More saved area which occupies the channels and ridges, controlling the lengths of the fields. Hassan (2004) recommended that using a gated pipes system increased wheat grain yield $6.5 \%$, giving application efficiency $76.5 \%$, water use efficiency 1.47 $\mathrm{kg} / \mathrm{m} 3$ saving $37.3 \%$ of irrigation water applied comparing with traditional method. Abd EI-Motaleb et al. (2006) mentioned that Controlled surface irrigation systems by using enclosed pipelines have been successfully demonstrated in recent years. The common type of pipes system is gated pipes technique. Cazanescu et al (2010) reported that effective land leveling optimizes water-use, reduces the irrigation time and the effort required to manage the crop. Also, it reduces crop management, and increases the yield and product quality. In areas with water excess, the soil leveling provides an appropriate water runoff, ensuring a better water management. Naresh et al (2014) Indicated that with laser leveling, farmers could save irrigation water $21 \%$, energy by $31 \%$ and obtained $10.9 \%$ sugarcane higher yields The laser leveled fields exhibited the highest water use efficiency (WUE), which was $49 \%$ higher in precisely leveled field than control (unleveled), $20 \%$ higher than traditionally leveling fields, respectively. The average water productivity in sugarcane has improved by $33 \%$. \%.

\section{MATERIALS AND METHODS}

The field experimental work was conducted at the farm of El-Mattana Research Station of the Agricultural Research Center, Luxor Governorate, Upper Egypt during growing season 2012/2013 on sugar cane crop. The sugarcane variety was Giza/Taiwan 54/C9 planted in furrows. The soil texture of the experimental site according to Black et al $\mathbf{1 9 6 5}$ is classified as clay soil as shown in Table (1). Field experimental work to study the effect of irrigation system and land slop technique under different furrow lengths on sugar cane production, water application efficiency, water distribution efficiency and water use efficiency under prevailing condition 
in Egyptian old valley also, its effects on advance and recession time, total water applied, yield and water use efficiency for sugar cane.

Table (1): The physical and mechanical analysis of the soil.

\begin{tabular}{|c|c|c|c|c|c|c|c|c|}
\hline \multirow{3}{*}{$\begin{array}{c}\text { Depth } \\
\mathrm{cm}\end{array}$} & \multicolumn{4}{|c|}{ Mechanical analysis } & \multirow{3}{*}{$\begin{array}{l}\text { Soil } \\
\text { texture }\end{array}$} & \multirow{3}{*}{$\begin{array}{c}\text { Field } \\
\text { capacity } \\
\%\end{array}$} & \multirow{3}{*}{$\begin{array}{c}\text { Wilting } \\
\text { point } \\
\%\end{array}$} & \multirow{3}{*}{$\begin{array}{c}\text { Bulk } \\
\text { density } \\
\mathrm{g} / \mathrm{cm}\end{array}$} \\
\hline & \multirow{2}{*}{ clay } & \multirow{2}{*}{ silt } & \multicolumn{2}{|c|}{ sand } & & & & \\
\hline & & & F.S & C.S & & & & \\
\hline $0-15$ & 56.62 & 19.61 & 16.2 & 7.57 & \multirow{4}{*}{ Clay } & 36.2 & 17.4 & 1.13 \\
\hline $15-30$ & 58.1 & 20.46 & 15.1 & 6.34 & & 38.1 & 18.1 & 1.15 \\
\hline $30-45$ & 55.85 & 22.14 & 16.15 & 5.86 & & 36.5 & 20.2 & 1.16 \\
\hline $45-60$ & 60.25 & 20.8 & 14.45 & 4.5 & & 35.8 & 19.0 & 1.17 \\
\hline
\end{tabular}

\section{Materials:}

\section{The gated pipe system calibration and test procedure:}

The gated pipes system designed for testing on the field were locally manufactured in the workshop of the Agricultural Research El-Mattana Research Station of the Agricultural Research Center, Upper Egypt, Luxor Governorate. The main objectives of the field experimental test procedure of gated pipe system were conducted to calibrate sliding rectangular plastic gate with a circular orifice $(3.8 \mathrm{~cm} \mathrm{D})$ along a $160 \mathrm{~mm}$. gated pipe system under different pressure heads and outlet areas. Also, aimed to examine the water uniformity distribution under the theoretical determination of suitable outlet areas along the $160 \mathrm{~mm}$. gated pipe. The flow rate recommended per meter width in clay soil was about $21 / \mathrm{s}$ as (Hassan 1998). Portable gated pipes system were manufactured using aluminum pipe had $160 \mathrm{~mm}$ outside diameter. The gates were located at approximately $0.75 \mathrm{~m}$ spacing (the same spacing between furrows) and had a circular shape of $38 \mathrm{~mm}$ in diameter when fully open. The pipe is available in 6-m length and uses quick coupler with rubber ring jointing. Each pipe had 8 gates. Therefore an 18-meter long of $160 \mathrm{~mm}$ outside pipe diameter was used with closed end having 24 sliding plastic gates. The connecting pipes, elbows, and fittings for the pumping unit were also locally manufactured, and the system was equipped with the required valves, Flow-meter, pressure gauge and peizometers.

\section{The pumping unit:}

Therefore the pumping unit discharge rate was adjusted to be as close as possible to pumping discharge rate $130 \mathrm{~m}^{3} / \mathrm{h}$ measured by 6 inches flow meter. The specifications of the pump was Shobra Diesel engine. The 
experimental field pumping unit operated by a diesel motor. The pump was connected through connecting tubes, spools, elbows, tees and other pipe fitting. The pump was equipped with an individual suction pipe and 5 inch hose ending with a trash screen and non- return valve.

\section{The utilized pipes for the gated pipe system:}

Six inch diameter, 6 meter length aluminum pipes were used for the gated pipe system. The pipes were connected together using rubber ring jointing system. The last one of the gated pipes system was equipped with gate valve at its end.

\section{Flow rate and pressure head measuring devices:}

\section{(a) The flow meter:}

A six inch flow meter was used to measure the flow entering the inlet of the gated pipe. The rate was obtained by dividing the recorder water quantity passed in the flow meter at a certain time by that time.

\section{(b) Spirit bubble level:}

Spirit bubble level was used to assure that the gated pipe was kept, as much as possible, in a horizontal position.

\section{(c) Glass mercury thermometer:}

A glass mercury thermometer was used to measure the temperature of the water passing in the gated pipe during the performed experiments.

\section{(d) A stop watch:}

Whenever time was concerned, it was measured using a stopwatch.

\section{(e) A galvanized bucket:}

A galvanized bucket of 15 liter capacity was used to collect the water discharge from each gate. The gate flow rate was, obtained by dividing the capacity of the bucket by the time determined to fill this bucket.

\section{(f) Steel tape scale:}

A steel tape scale was used to measure the height of water in the water hose manometers.

\section{(g) Linen scale tape:}

The linen scale tape of $50 \mathrm{~m}$ long was used to measure the land dimensions.

\section{(h) Pressure gauge:}

The pumping unit discharge head was measured using a pointer pressure gauge fixed just before the flow- meter. Its reading range was from 0.0 to 
0.6 bars with $10 \mathrm{~cm}$ increment and fixed one at each pipe just before the inlet pipe.

\section{Method:}

\section{Field experimental work:}

Field experimental work to study the effect of irrigation system and land leveling technique under different furrows lengths on the sugarcane production and its components, water application efficiency, water distribution efficiency and water use efficiency under prevailing condition in Egyptian old valley also, its effects on advance and recession time, total water applied, yield and water use efficiency for sugarcane.

\section{Field experimental test procedure:}

Field experimental work to study the effect of irrigation system and land leveling technique under different furrows lengths on the sugarcane production and its components, water application efficiency, water distribution efficiency and water use efficiency under prevailing condition in Egyptian old valley also, its effects on advance and recession time, total water applied, yield and water use efficiency for sugarcane. An experimental area plot was about 3.4 feddan. The experimental area plot was divided into 2 sub-plots each of 1.7 feddan as shown in Fig. (1).

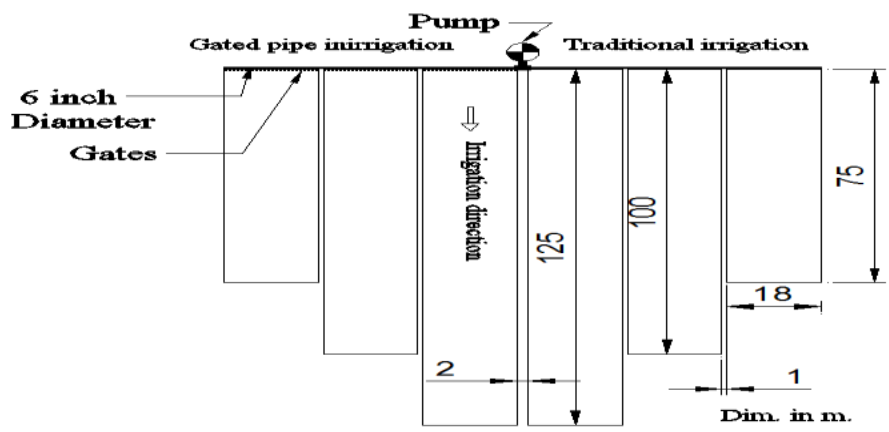

Fig (1): The layout of experiment.

The first sub-plot was leveled at zero slopes and irrigated by traditional method. The second sub-plot leveled at $0.1 \%$ slope by laser technique and irrigated by gated pipe system. Each sub-plot was divided into three treatments 75 meters furrow length $\left(\mathrm{L}_{75}\right), 100$ meters furrow length $\left(\mathrm{L}_{100}\right)$ and $125 \mathrm{~m}$ furrow length $\left(\mathrm{L}_{125}\right)$. The width of the field test for each treatment was $18 \mathrm{~m}$ and 1-m strip of untilled land was thus left between 
adjacent treatments. Also, $2 \mathrm{~m}$ strip of untilled land was thus left between adjacent sub-plots. The first area sub-plot was irrigating with traditional method by pumped irrigation water through 6 inch flow meter into a concrete canal to flow from the canal to the furrows. The second experimental area sub-plot was irrigating by 6 inch diameter aluminum gated pipes. The distance between two consecutive furrows was to be $0.75 \mathrm{~m}$. Each treatment was serving by 6 inch gated pipe having $6 \mathrm{~m}$ length and the required gates. The flow rate recommended per meter width in clay soil was about 2 1/s as (Hassan 1998).

\section{a- Hydraulic characteristics:}

The hydraulic characteristics of each outlet are directly related to the mode of fluid motion (flow regime) inside the orifice as characterized by the Reynolds number calculated according to Jensen (1980) as follow:

$R N=v d / v$

Where:

$\mathrm{V}$ is fluid flow velocity $(\mathrm{m} / \mathrm{s}), \mathrm{d}$ is the orifice diameter $(\mathrm{m})$ and $v$ is kinematics viscosity $\left(\mathrm{m}^{2} / \mathrm{s}\right)$.

The mathematical relationship relates the affecting factors with water distribution rates and uniformity for perforated tube. He also reported that the total friction head losses inside the perforated pipe and the superimposed pressure head are estimated by Morcos et al. (1994) as follows equations:

$$
\begin{aligned}
& Q_{n}=\sum_{\mathrm{n}=1}^{\mathrm{N}} \mathrm{q}_{\mathrm{n}} \\
& \mathrm{Vn}=0.001 \mathrm{Q} / \mathrm{A} \\
& h_{f n}=\mathrm{k}\left[\mathrm{Q}_{\mathrm{n}} / \mathrm{CHw}\right]^{1.852} \times \mathrm{D}^{-4.87} \times \mathrm{S} \\
& h f t=\sum_{\mathrm{n}=1}^{\mathrm{N}} \mathrm{h}_{\mathrm{fn}}, \mathrm{m} \\
& \left.H s n=\left(V_{\max }^{2}-V_{n}^{2}\right) / 2 \text { g. }\right) \\
& \text { Hcom }=\text { hp }+ \text { Hsn }- \text { hft } \\
& \text { qn }=3.479(\mathrm{dcom})^{2}(\text { Hcom })^{0.5}
\end{aligned}
$$


$\mathrm{D} \quad=$ Inside perforated pipe diameter, $\mathrm{mm}$.

$\mathrm{S} \quad=$ The spacing between outlets along the perforated pipe, $\mathrm{m}$.

$\mathrm{CHw}=$ Hazen William, $\mathrm{s}$ coefficient, dimensionless.

$\mathrm{h}_{\mathrm{fn}} \quad=$ The friction head losses inside the perforated pipe just before any outlet, $\mathrm{m}$.

$\mathrm{h}_{\mathrm{ft}}=$ Total friction head losses inside the perforated pipe just before any outlet, $\mathrm{m}$.

$\mathrm{V}_{\mathrm{n}} \quad=$ Flow velocity inside the perforated pipe just before any outlet, $\mathrm{m} / \mathrm{s}$.

$\mathrm{A} \quad=$ The perforated pipe cross section area, $\mathrm{m}^{2}$.

Hsn $=$ The superimposed pressure head, $\mathrm{m}$.

$\mathrm{V}_{\max }=$ Maximum inside flow velocity at perforated pipe inlet, $\mathrm{m} / \mathrm{s}$.

$\mathrm{g}=$ Gravitational field, $\mathrm{m} / \mathrm{s}^{2}$.

$\mathrm{H}_{\mathrm{com}}=$ The resultant pressure head, $\mathrm{cm}$.

$\mathrm{d}_{\mathrm{com}}=$ The computed outlet diameter, $\mathrm{m}$.

The coefficient of discharge may be defined as the ratio between actual discharge and the theoretical discharge passing through an orifice, it is denoted by Cd Massey (1990).

Mathematically; $\mathrm{C} \mathrm{d}=$ Actual discharge / Theoretical discharge

Determine the discharge rate " $q$ " and its coefficient "Cd" for heads " $h$ " and gate opening - areas " a" , calculated according to Awady (2002) the well - known formula:

$q=c d$ a $\sqrt{2 \mathrm{gh}}$

Where: "g" is the gravitational acceleration. Also, gate opening and the corresponding width " $a, w$ " were also estimated for uniform discharge along level line, " $w$ " was estimated by approximately the aperture into square area calculated according to Awady (2002).

$W=d\left(a / a_{0}\right)$

Where $\left(a_{0}\right)$ is the area of fully - open gate and $(\mathrm{d})=38 \mathrm{~mm}$.

\section{b-The variation of flow through gated pipe system $\left(q_{\mathrm{var}}\right)$ :}

The flow variation along the lateral line can be determined by Jensen (1980) as follow.

$q_{\mathrm{var}}=q_{\max }-q_{\min } / q_{\max }$

Where:

$\mathrm{q}_{\mathrm{var}}=$ The outlet flow variation $\%$, 
$\mathrm{q}_{\max }=$ The maximum outlet flow along the lateral line.

$\mathrm{q}_{\min }=$ The minimum outlet flow along the lateral line.

\section{c-The pressure head variation through gated pipe system:}

The pressure head variation can be determined by Chu (1984), Wu and Gitlin (1983), Kincaid and Kemper (1982) as follow:

$\mathrm{H}_{\mathrm{var}}=\left(\mathrm{H}_{\max }-\mathrm{H}_{\min }\right) / \mathrm{H}_{\max }$

Where:

$\mathrm{H}_{\mathrm{var}}=$ pressure head variation along sub-main,

$\mathrm{H}_{\max }=$ maximum pressure head in sub-main, $\mathrm{m}$, and

$\mathrm{H}_{\text {min }}=$ minimum pressure head in sub-main, $\mathrm{m}$

d- The water application efficiency (WAE):

The water application efficiency was computed according formula Jensen (1980) as follows:

$\mathrm{WAE}=$ (Average depth of water infiltrated and stored into root zone /Average depth of water applied) $\mathrm{x} 100$

\section{e- Water distribution efficiency (WDE):}

Water distribution efficiency indicates the extent to which water is uniformly distribution along the run. Israelsen and Hansen (1962) as defined it:

$$
W D E=\left[1.0-\left(\sum\left|Y_{i}-d\right|\right) /(N \times d)\right]
$$

Where:

$W D E=$ Water distribution efficiency, percent.

$d \quad=$ Average depth of water stored along the run during the irrigation.

$\left|Y_{i}-d\right|=$ Average absolute numerical deviation from $\mathrm{d}$.

$N \quad=$ Number of readings

\section{f- Water use efficiency (WUE):}

Values were calculated according to Jensen (1983) as follows:

WUE $=$ Sugar cane yield $\left(\mathrm{kg} / \mathrm{fed}\left(\mathrm{kg} / \mathrm{m}^{3}\right) /\right.$ Applied irrigation water $\left(\mathrm{m}^{3} /\right.$ fed. $)$.

\section{RESULTS AND DISCUSSION}

The practical of performance of the designed and locally manufactured gated pipe system:

The field experimental work covered on experimental computation of the flow head inside the design and locally manufactured of gated pipe 
system and its calibration experimentally on the operating field condition. The theoretical calculation of the flow head inside the design and locally manufactured gated pipe along its whole length based on the actual flow rate and actual pressure head experimentally measured from the pumping unit. The theoretical determination and calculation in predicting the flow pressure head at each outlet along the gated pipe system was carried out to estimate the expected suitable outlets diameters along the gated pipe giving the flow rate recommended per each furrows $(1.51 / \mathrm{s})$ by using step- step method proposed by Morcos et.al. 1994. The results of the theoretical computation of the outlets diameters along the gated pipe and the outlets flow rates experimentally measured are shown in Table (2).

Table (2): Outlets number along the gated pipe system (No),

\begin{tabular}{|c|c|c|c|c|c|c|c|c|c|c|c|c|c|c|c|}
\hline $\begin{array}{l}\text { No. } \\
\text { gate }\end{array}$ & $\begin{array}{l}\text { Qn, } \\
\text { l/s }\end{array}$ & $\begin{array}{l}\mathbf{V n} \\
\mathbf{m} / \mathbf{s} \\
\end{array}$ & $\begin{array}{c}\text { Hsn, } \\
\text { m }\end{array}$ & RNn & $\begin{array}{c}\text { hfn, } \\
\text { m }\end{array}$ & $\begin{array}{c}\text { Hft, } \\
\text { m }\end{array}$ & $\begin{array}{c}\text { Hcom, } \\
\text { m }\end{array}$ & $\begin{array}{l}\mathbf{v}_{\text {th }} \\
\mathrm{m} / \mathrm{s}\end{array}$ & $\begin{array}{c}\mathbf{a}, \\
\mathbf{c m}^{2}\end{array}$ & $\begin{array}{c}\mathbf{h}_{\mathbf{m}} \\
\mathbf{m}\end{array}$ & $\begin{array}{l}\mathbf{v}_{\text {th }}, \\
\mathrm{m} / \mathrm{s}\end{array}$ & $\begin{array}{l}\mathbf{q}_{\mathrm{th}}, \\
\mathrm{m} / \mathrm{s}\end{array}$ & $\begin{array}{l}\mathbf{q}_{\mathrm{m}}, \\
\mathrm{l} / \mathrm{s}\end{array}$ & cd & $\begin{array}{l}\mathbf{w}, \\
\text { cm }\end{array}$ \\
\hline 1 & 36 & 2.03 & 0.00 & $2.70 \mathrm{E}+05$ & 0.02 & 0.02 & -0.73 & 3.785 & 4.175 & 0.732 & 3.790 & 1.582 & 1.580 & 0.999 & 1.400 \\
\hline 2 & 34.5 & 1.95 & 0.02 & $2.59 \mathrm{E}+05$ & 0.02 & 0.04 & -0.72 & 3.770 & 4.164 & 0.727 & 3.777 & 1.573 & 1.570 & 0.998 & 1.397 \\
\hline 3 & 33 & 1.86 & 0.03 & $2.47 \mathrm{E}+05$ & 0.02 & 0.06 & -0.72 & 3.758 & 4.124 & 0.708 & 3.727 & 1.537 & 1.550 & 1.008 & 1.383 \\
\hline 4 & 31.5 & 1.78 & 0.05 & $2.36 \mathrm{E}+05$ & 0.02 & 0.08 & -0.72 & 3.749 & 4.001 & 0.706 & 3.722 & 1.489 & 1.500 & 1.007 & 1.342 \\
\hline 5 & 30 & 1.69 & 0.06 & $2.25 \mathrm{E}+05$ & 0.02 & 0.10 & -0.71 & 3.742 & 3.981 & 0.693 & 3.687 & 1.468 & 1.490 & 1.015 & 1.335 \\
\hline 6 & 28.5 & 1.61 & 0.08 & $2.14 \mathrm{E}+05$ & 0.02 & 0.12 & -0.71 & 3.738 & 3.960 & 0.692 & 3.685 & 1.459 & 1.480 & 1.014 & 1.328 \\
\hline 7 & 27 & 1.53 & 0.09 & $2.02 \mathrm{E}+05$ & 0.01 & 0.13 & -0.71 & 3.735 & 3.962 & 0.708 & 3.727 & 1.477 & 1.480 & 1.002 & 1.329 \\
\hline 8 & 25.5 & 1.44 & 0.11 & $1.91 \mathrm{E}+05$ & 0.01 & 0.14 & -0.71 & 3.735 & 3.963 & 0.712 & 3.738 & 1.481 & 1.480 & 0.999 & 1.329 \\
\hline 9 & 24 & 1.36 & 0.12 & $1.80 \mathrm{E}+05$ & 0.01 & 0.16 & -0.71 & 3.736 & 3.961 & 0.723 & 3.766 & 1.492 & 1.480 & 0.992 & 1.329 \\
\hline 10 & 22.5 & 1.27 & 0.13 & $1.69 \mathrm{E}+05$ & 0.01 & 0.17 & -0.71 & 3.739 & 3.959 & 0.730 & 3.785 & 1.498 & 1.480 & 0.988 & 1.328 \\
\hline 11 & 21 & 1.19 & 0.14 & $1.57 \mathrm{E}+05$ & 0.01 & 0.18 & -0.71 & 3.743 & 3.874 & 0.736 & 3.800 & 1.472 & 1.450 & 0.985 & 1.299 \\
\hline 12 & 19.5 & 1.10 & 0.15 & $1.46 \mathrm{E}+05$ & 0.01 & 0.18 & -0.72 & 3.748 & 3.869 & 0.736 & 3.800 & 1.470 & 1.450 & 0.986 & 1.298 \\
\hline 13 & 18 & 1.02 & 0.16 & $1.35 \mathrm{E}+05$ & 0.01 & 0.19 & -0.72 & 3.754 & 3.783 & 0.742 & 3.815 & 1.443 & 1.420 & 0.984 & 1.269 \\
\hline 14 & 16.5 & 0.93 & 0.17 & $1.24 \mathrm{E}+05$ & 0.01 & 0.20 & -0.72 & 3.761 & 3.776 & 0.746 & 3.826 & 1.445 & 1.420 & 0.983 & 1.266 \\
\hline 15 & 15 & 0.85 & 0.17 & $1.12 \mathrm{E}+05$ & 0.00 & 0.20 & -0.72 & 3.768 & 3.875 & 0.748 & 3.831 & 1.484 & 1.460 & 0.984 & 1.300 \\
\hline 16 & 13.5 & 0.76 & 0.18 & $1.01 \mathrm{E}+05$ & 0.00 & 0.20 & -0.73 & 3.776 & 3.867 & 0.748 & 3.831 & 1.481 & 1.460 & 0.986 & 1.297 \\
\hline 17 & 12 & 0.68 & 0.19 & $9.00 \mathrm{E}+04$ & 0.00 & 0.21 & -0.73 & 3.783 & 3.912 & 0.748 & 3.831 & 1.499 & 1.480 & 0.988 & 1.312 \\
\hline 18 & 10.5 & 0.59 & 0.19 & $7.87 \mathrm{E}+04$ & 0.00 & 0.21 & -0.73 & 3.791 & 3.904 & 0.750 & 3.836 & 1.498 & 1.480 & 0.988 & 1.309 \\
\hline 19 & 9 & 0.51 & 0.20 & $6.75 \mathrm{E}+04$ & 0.00 & 0.21 & -0.74 & 3.799 & 3.949 & 0.750 & 3.836 & 1.515 & 1.500 & 0.990 & 1.324 \\
\hline 20 & 7.5 & 0.42 & 0.20 & $5.62 \mathrm{E}+04$ & 0.00 & 0.21 & -0.74 & 3.806 & 3.994 & 0.754 & 3.846 & 1.536 & 1.520 & 0.989 & 1.340 \\
\hline 21 & 6 & 0.34 & 0.20 & $4.50 \mathrm{E}+04$ & 0.00 & 0.21 & -0.74 & 3.812 & 4.066 & 0.756 & 3.851 & 1.566 & 1.550 & 0.990 & 1.364 \\
\hline 22 & 4.5 & 0.25 & 0.21 & $3.37 \mathrm{E}+04$ & 0.00 & 0.21 & -0.74 & 3.817 & 4.166 & 0.758 & 3.856 & 1.606 & 1.590 & 0.990 & 1.397 \\
\hline 23 & 3 & 0.17 & 0.21 & $2.25 \mathrm{E}+04$ & 0.00 & 0.22 & -0.74 & 3.821 & 4.266 & 0.760 & 3.862 & 1.647 & 1.630 & 0.990 & 1.431 \\
\hline 24 & 1.5 & 0.06 & 0.21 & $8.47 \mathrm{E}+03$ & 0.00 & 0.22 & -0.75 & 3.824 & 4.315 & 0.764 & 3.872 & 1.671 & 1.650 & 0.988 & 1.447 \\
\hline
\end{tabular}


Table (2) expected and measured performance of the design and locally manufactured of gated pipe system based on the experimental pumping unit flow rate $130 \mathrm{~m}^{3} / \mathrm{h}$ and pumping unit discharge head of $75 \mathrm{~cm}$ of water flow rate recommended ( $\left.\mathrm{q}_{\mathrm{rec}}\right)$ per each outlet $(1.5 \mathrm{l} / \mathrm{s})$, the average flow velocity inside the gated pipe system just before any outlet $\left(\mathrm{V}_{\mathrm{n}}\right), \mathrm{m} / \mathrm{s}$ computed by using equation (2), the head losses due to friction just before any outlet $\left(\mathrm{h}_{\mathrm{ft}}\right), \mathrm{m}$, computed by using equation (4) through equation (5), the pressure head generated due to the decreasing in the flow velocity inside the gated pipe system $\left(\mathrm{H}_{\mathrm{Sn}}\right), \mathrm{m}$, along the gated pipe system computed by using equation (6), the outlets pressure heads expected $\left(\mathrm{H}_{\mathrm{com}}\right), \mathrm{m}$, computed by using equation (7), the outlet diameter computed $\left(\mathrm{d}_{\mathrm{o}}\right), \mathrm{mm}$ computed by using equation (10). Also the original pressure head $\left(\mathrm{h}_{\mathrm{m}}\right)$ was measured using Piezometeric tube and the actual measured outlet flow rate experimentally measured along the gated pipe $\left(\mathrm{q}_{\mathrm{m}}\right), 1 / \mathrm{s}$ by using direct method. The results of Table (2) show that the most flow in gated pipe system occurs at Reynolds number between $10^{3}, 10^{4}$ and $10^{5}$ and the flow was about fully turbulent flow agreement with Kincaid and Kemper (1982). There were slightly deviation between outlets flow measured along the gated pipe system and the outlets flow recommended per each furrow, but there were deviation between outlets flow measured $\left(\mathrm{q}_{\mathrm{m}}\right)$ along the gated pipe system and the theoretical computation of outlets flow rates ( $\mathrm{q}_{\mathrm{rec}}$ ) computed as equation (9) due to coefficient of discharge resulting from the outlets manufacturing. Concerning the total head losses due to friction was increased gradually until reached $8.4 \%$ of the original pumping pressure head measured. But the pressure head generating due to decrease in flow velocity along the gated pipe system increased towards the tube dead end until reached about $12.5 \%$ of the original pumping pressure head measured. The flow variation through 18 meters apart of the gated pipe system computed as equation (12) was about $13.9 \%$. Therefore the uniformity distribution of flow through outlets along the gated pipe system was about $86.1 \%$. On the other hand pressure head variation computed by equation (13) was about $9.42 \%$. The pressure head increasing gradually until reached the maximum at the tube dead end due to the increasing in pressure head gained overcome the pressure head losses by friction. 


\section{Advance and recession times:}

Figs. (2), (3) and (4) respectively are show that three replicates of advance, recession and opportunity times.

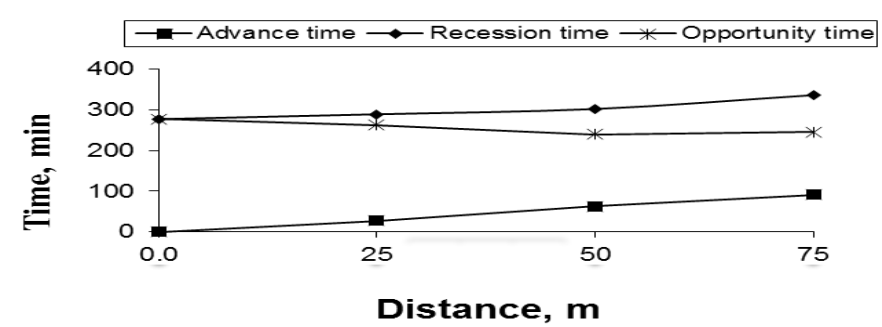

Fig (2) Advance, recession and opportunity times curves for traditional irrigation method under (L75)
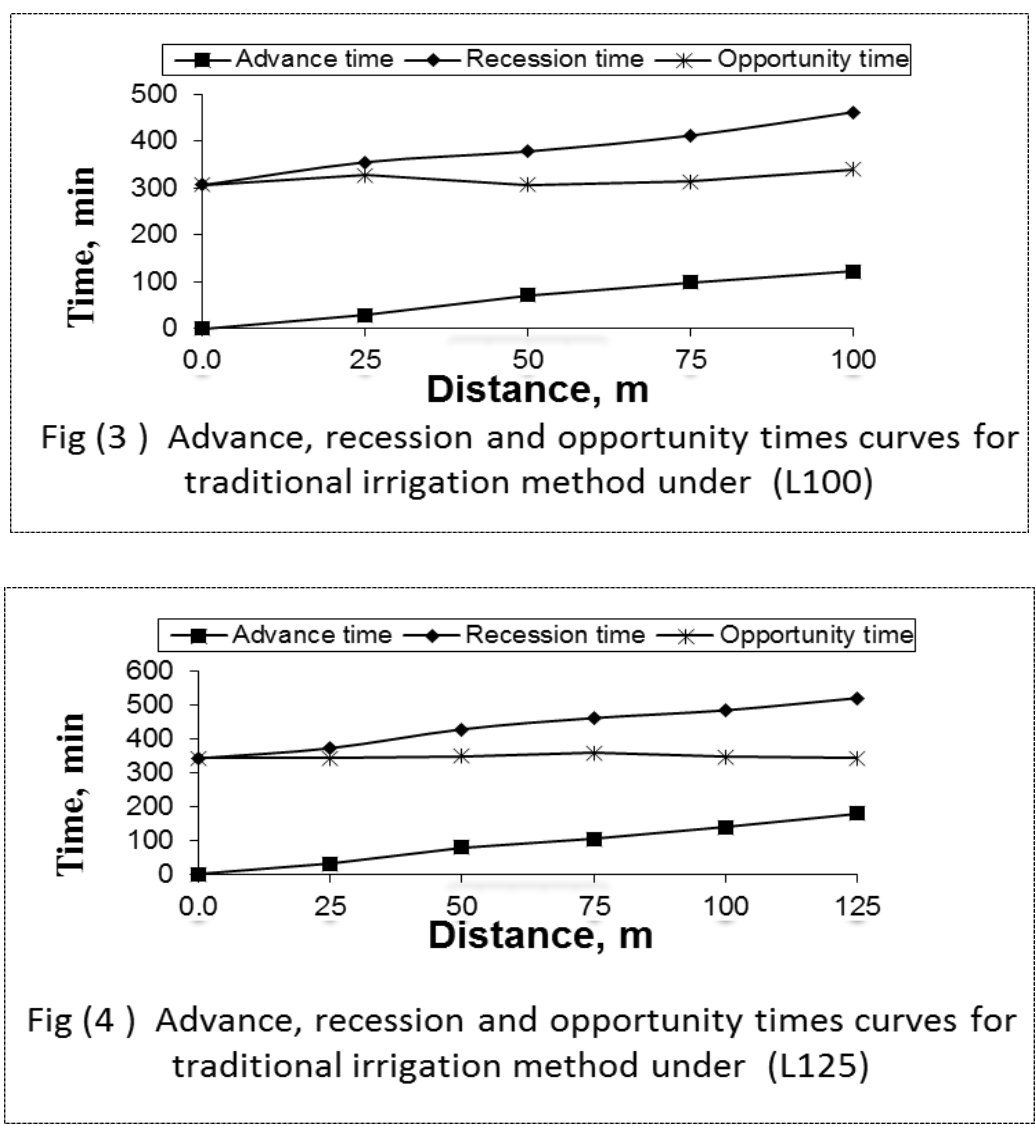

The values through three replicates of advance, recession and opportunity times for traditional irrigation methods $\left(\mathrm{T}_{1}\right)$ under different treatment of furrows lengths $\mathrm{L}_{75}, \mathrm{~L}_{100}$ and $\mathrm{L}_{125}$. 
The values through three replicates of advance, recession and opportunity times for gated pipe irrigation methods $\left(\mathrm{T}_{2}\right)$ under different treatment of furrows lengths $\mathrm{L}_{75}, \mathrm{~L}_{100}$ and $\mathrm{L}_{125}$ are shown in Figs.(5), (6) and (7) respectively.

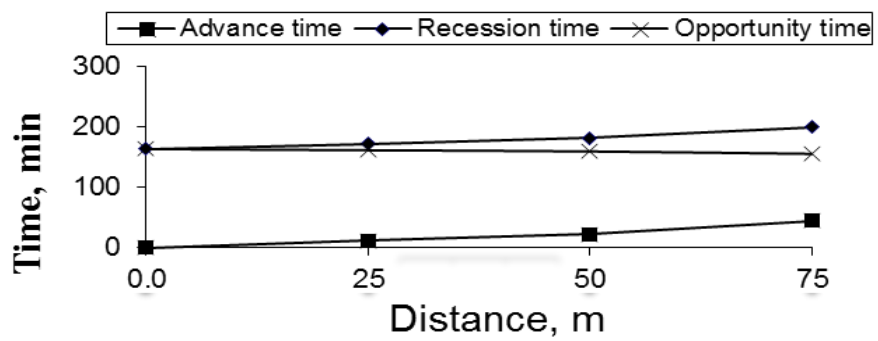

Fig (5) Advance, recession and opportunity times curves for gated pipe irrigation method under slope $0.1 \%$ (L75)

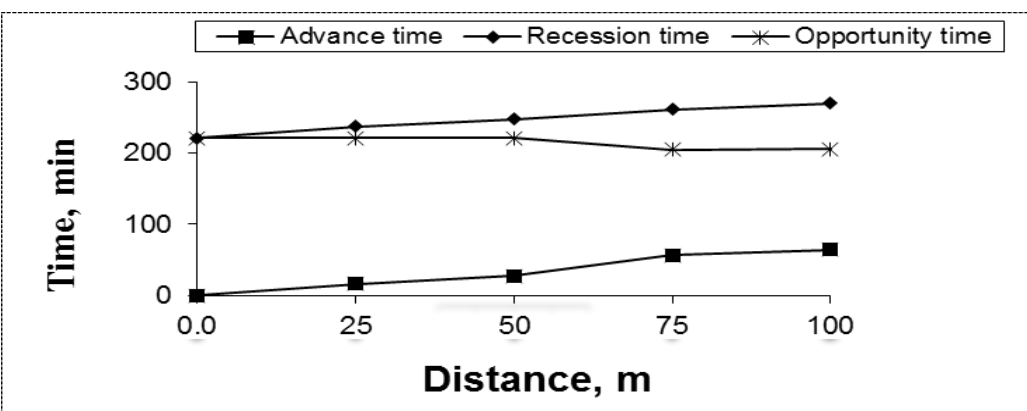

Fig (6) Advance, recession and opportunity times curves for gated pipe irrigation method under slope $0.1 \%$ (L100)

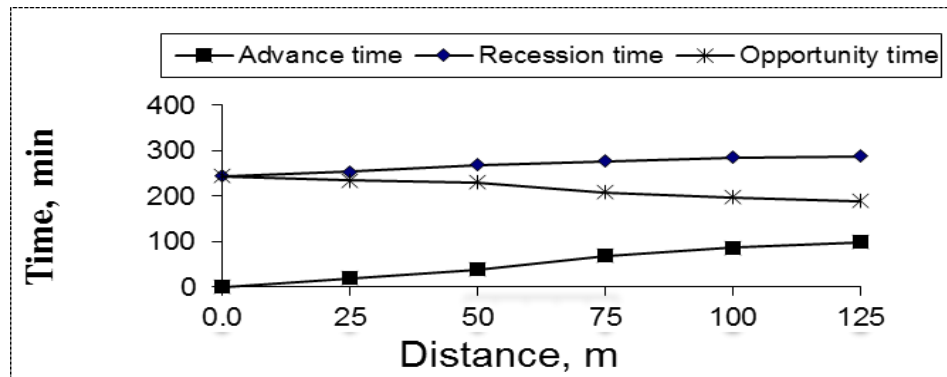

Fig (7) Advance, recession and opportunity times curves for gated pipe irrigation method under slope $0.1 \%$ (L125) 
The results gave the same trend as traditional method or gated pipe system of increasing the advance and recession times as furrows length increased. The opportunity time for irrigation with gated pipe system decreased by $36.7,39.4$ and $44.7 \%$ than traditional irrigation method under treatment of furrows lengths $\mathrm{L}_{75}, \mathrm{~L}_{100}$ and $\mathrm{L}_{125}$ respectively due to $0.1 \%$ slope and good water irrigation distribution by gated pipe system.

\section{Amounts of irrigation water:}

The average total amounts of water received by sugarcane plants during two seasons through 22 irrigations for traditional $\left(T_{1}\right)$ and gated pipe system $\left(\mathrm{T}_{2}\right)$ under different treatment of furrows lengths $\mathrm{L}_{75}, \mathrm{~L}_{100}$ and $\mathrm{L}_{125}$ respectively are shown in Fig. (8). The figure shows that the results gave the same trend as traditional method or gated pipe system of increasing the average total amounts of water for traditional methods through replicates under treatment $\mathrm{L}_{75}, \mathrm{~L}_{100}$ and $\mathrm{L}_{125}$ respectively.

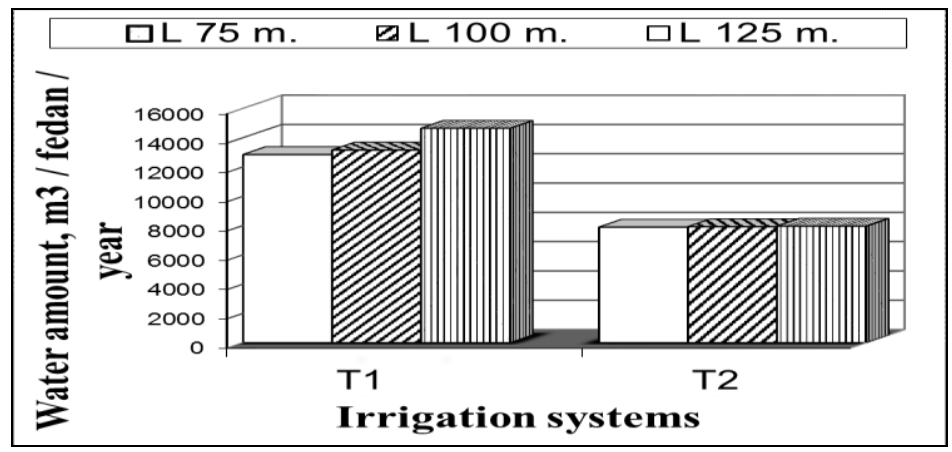

Fig. (8): Effect of irrigation systems and furrows lengths on the total irrigation amount of sugarcane crop.

Also, the figure showed that in the three cases of treatment for furrows lengths $\mathrm{L}_{75}, \mathrm{~L}_{100}$ and $\mathrm{L}_{125}$ for traditional or gated pipe systems, the sugarcane plant received more amounts of irrigation water as furrow length increased due to increased water opportunity time, as furrow length increased. Thus water losses with seepage, evaporation and run off increased. The result revealed that the traditional methods received more amounts of irrigation water than gated pipe system in the three cases of furrow lengths due to good uniformity of water application gives good water distribution from outlets along the furrow lengths width on the upper part of the field. Also, using laser land leveling technique at $0.1 \%$ 
slope decreased the water losses by both deep percolation and runoff due to decrease the advance time and opportunity time.

\section{Water saving \%:}

The values of water saving $\%$ for traditional irrigation method $\left(\mathrm{T}_{1}\right)$ and irrigation using gated pipe system $\left(\mathrm{T}_{2}\right)$ were affected by different furrows lengths and slope as shown in Fig. (9).

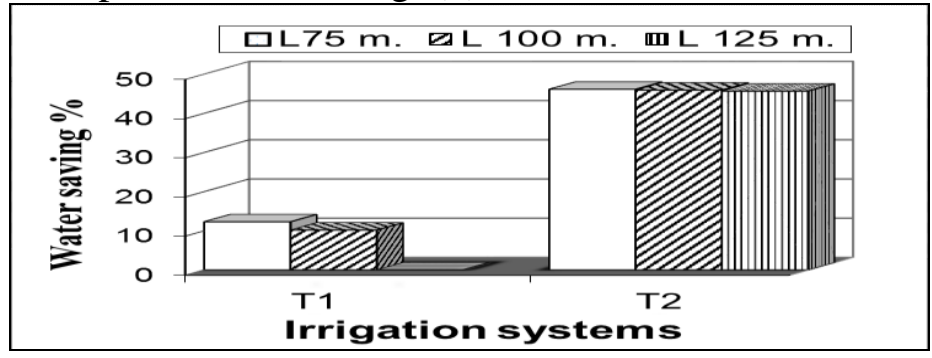

Fig. (9): Effect of irrigation systems and furrows lengths on water saving.

The results indicated that the effect of $T_{1}$ and $T_{2}$ on water saving the highest values water saving were achieved by using irrigation gated pipe technique with leveling by laser technique $0.1 \%$ slope at three cases of furrows lengths $\mathrm{L}_{75}, \mathrm{~L}_{100}$ and $\mathrm{L}_{125}$ respectively, compared with traditional irrigation method. The maximum value of water saving $\%$, for the irrigation with gated pipe system was achieved in the case of treatment $\mathrm{L}_{75}$. Generally the highest values water saving which may be due to the highest amount of water applied followed by the traditional irrigation method. Also, using laser land leveling technique at $0.1 \%$ slope decreased the water losses by both deep percolation and runoff due to decrease the advance time and opportunity time and the improved water distribution along the furrow.

\section{Water application efficiency (WAE. \%):}

The average depths of the irrigation water stored in the root zone for both irrigation traditional and gated pipe systems under treatment $\mathrm{L}_{75}, \mathrm{~L}_{100}$ and $\mathrm{L}_{125}$ depending on soil moisture content before and after each irrigation was $36.5 \mathrm{~cm}$. The average actual depths of irrigation water applied through traditional irrigation method were 74.4, 76.2 and $84.8 \mathrm{~cm}$ under the treatments $\mathrm{L}_{75}, \mathrm{~L}_{100}$ and $\mathrm{L}_{125}$ respectively. On the other hand, the average actual of irrigation water applied through irrigation using gated 
pipe system were $45.63,45.9$ and $46.1 \mathrm{~cm}$ for the treatments $\mathrm{L}_{75}, \mathrm{~L}_{100}$ and $\mathrm{L}_{125}$ respectively. The average values of water application efficiency (WAE) of sugarcane during two season for traditional irrigation $\left(\mathrm{T}_{1}\right)$ and irrigation with gated pipe system $\left(\mathrm{T}_{2}\right)$ were affected by different furrows lengths as shown in Fig. (10).

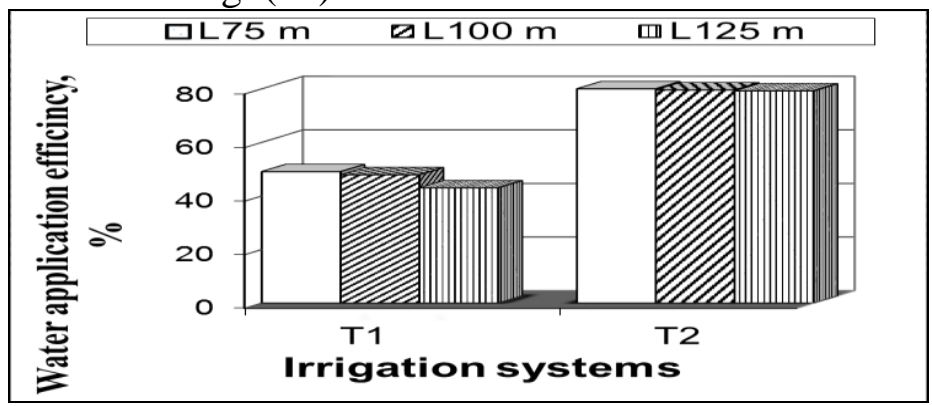

Fig. (10): Effect of irrigation systems and furrows lengths on the water application efficiency.

The figure showed that the results gave the trend as traditional method or gated pipe system of decreased the water application efficiency as furrows length increased. The results revealed that the value of water application efficiency for traditional irrigation method was achieved in case of treatment $\mathrm{L}_{75}$ due to increase total water consumptive use in the two other treatments $\mathrm{L}_{100}$ and $\mathrm{L}_{125}$ due to increase water irrigation losses by runoff, deep percolation and evaporation. On the other hand, increasing opportunity time increases water losses by evaporation and seepage. The maximum value of water use efficiency for the irrigation with gated pipe was achieved in the case of treatments $\mathrm{L}_{75}$ more than treatment $\mathrm{L}_{100}$ and $\mathrm{L}_{125}$ due to increased water irrigation losses by deep percolation and seepage as furrows lengths increased. The results indicate that the increasing in water application efficiency for irrigation with gated pipe was larger than the values of water application efficiency achieved by traditional irrigation under the three cases of treatments $\mathrm{L}_{75}, \mathrm{~L}_{100}$ and $\mathrm{L}_{125}$ due to increased total irrigation water amounts consumed per feddan at the same condition of using gated pipe system. The increasing in total irrigation water amounts consumed per feddan for the traditional irrigation method due to increasing the advance time, consequently increasing the opportunity time and causing increased water losses by deep percolation, run off and evaporation. In conclusion, the result 
revealed that the traditional irrigation $\left(\mathrm{T}_{1}\right)$ gave lower water application efficiency than irrigation using gated pipe system $\left(\mathrm{T}_{2}\right)$. Also, $\mathrm{L}_{75}$ in the case of using gated pipe system gave the highest water application efficiency due to the decrease in the water irrigation losses by deeppercolation, evaporation and runoff by good laser technique land leveling at $0.1 \%$ slop, closed conduit to carry water to the field and good irrigation water distribution along the furrows over the upper part of the field through outlets.

\section{Water distribution efficiency (WDE) \%:}

The values of water distribution efficiency (WDE) for traditional irrigation method $\left(T_{1}\right)$ and irrigation using gated pipe system $\left(T_{2}\right)$ were affected by different furrows lengths and slope as shown in Fig. (11).

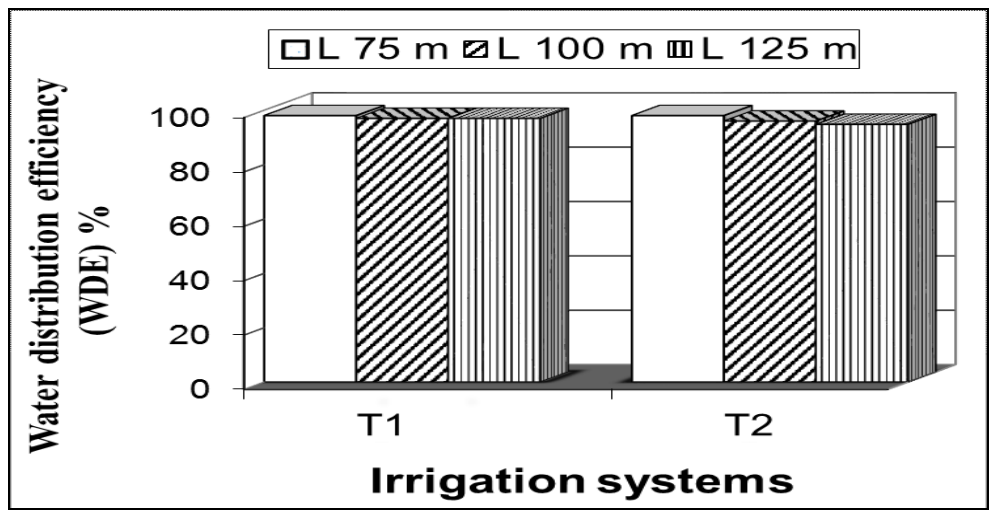

Fig. (11): Effect of irrigation systems and furrows lengths on water distribution efficiency.

The results indicate that the average of water distribution efficiency for traditional irrigation and irrigation with gated pipe under treatments $\mathrm{L}_{75}$, $\mathrm{L}_{100}$ and $\mathrm{L}_{125}$ by $97.3 \%$ and $97.8 \%$. The results showed that there is little difference between the water distribution efficiency for traditional irrigation and irrigation with gated pipe due to good coverage all the ground by water.

\section{Yield:}

Under the different irrigation method $\left(\mathrm{T}_{1}\right)$ and $\left(\mathrm{T}_{2}\right)$ the values during the sugarcane yield were achieved in case of treatment $\mathrm{L}_{75}, \mathrm{~L}_{100}$ and $\mathrm{L}_{125}$ furrows length of as shown in Fig. (12). 


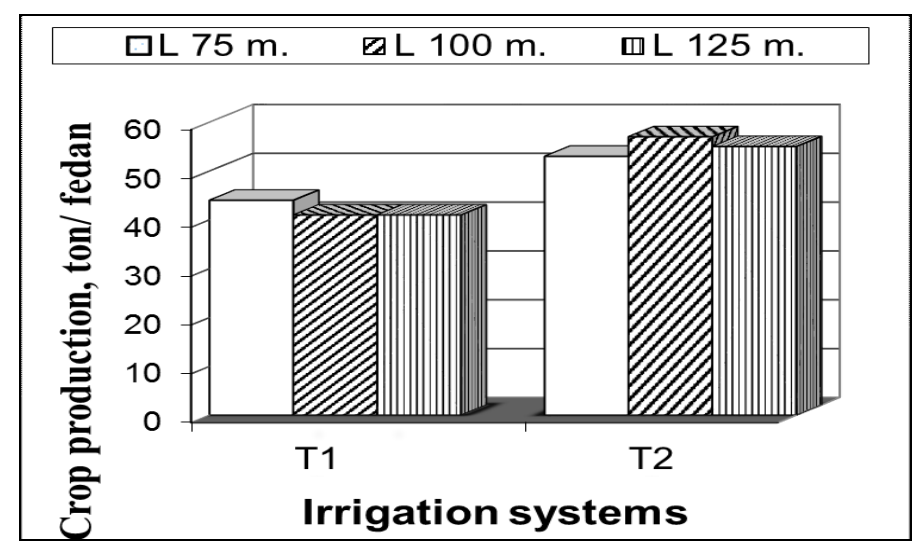

Fig. (12): Effect of irrigation systems and furrows lengths on yield of sugarcane.

The results indicate that the increasing furrows lengths to $\mathrm{L}_{75}, \mathrm{~L}_{100}$ and $\mathrm{L}_{125}$ in case of treatment $\left(\mathrm{T}_{1}\right)$ decreasing the average values of sugarcane yield by about $6.8 \%$. On the other hand the values of crop production by gated pipe irrigation system under $0.1 \%$ land slope and different treatment of furrow length $\mathrm{L}_{75}, \mathrm{~L}_{100}$ and $\mathrm{L}_{125}$ respectively, increasing furrows lengths to $\mathrm{L}_{75}, \mathrm{~L}_{100}$ in case of treatment $\left(\mathrm{T}_{2}\right)$ increasing the values of sugarcane yield by about $7.54 \%$ and increasing furrows lengths to $\mathrm{L}_{100}$, $\mathrm{L}_{125}$ decreasing the values of sugarcane yield by about $3.51 \%$. Concerning the effect of $T_{1}$ and $T_{2}$ increasing values sugarcane yield were achieved in case of using irrigation gated pipe technique with leveling by laser technique $0.1 \%$ slope at three cases of furrows lengths $\mathrm{L}_{75}, \mathrm{~L}_{100}$ and $\mathrm{L}_{125}$ respectively, by 11,16 and 12 ton/ fed respectively, compared with traditional irrigation method which may be due to the improved water distribution along the furrow. From the above mentioned discussion, it could be concluded that using gated pipe system at furrows length of 100 $\mathrm{m}$ and after laser land leveling with $0.1 \%$ slope for the sugarcane gives the highest values sugarcane yield of sugarcane crop.

\section{Water use efficiency (WUE):}

The values of water use efficiency (WUE) of sugarcane yield for traditional irrigation method $\left(\mathrm{T}_{1}\right)$ and irrigation using gated pipe system $\left(\mathrm{T}_{2}\right)$ were affected by different furrows lengths and slope as shown in Fig. (13). 


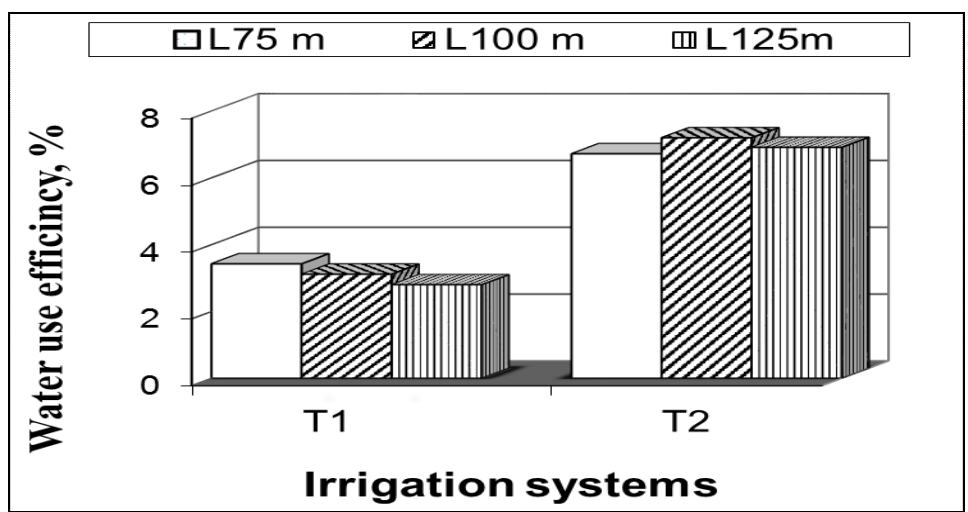

Fig. (13): Effect of irrigation systems and furrows lengths on (WUE) of sugarcane.

The results revealed that the maximum value of WUE for traditional irrigation was achieved in the case of treatment $\mathrm{L}_{75}$. However, the maximum value of WUE for the irrigation with gated pipe system was achieved in the case of treatment $\mathrm{L}_{100}$. The results showed that the irrigation gated pipe increasing WUE by $48.95,56.66$ and $59.47 \%$ under treatments $\mathrm{L}_{75}, \mathrm{~L}_{100}$ and $\mathrm{L}_{125}$ respectively compared with the traditional irrigation method, due to decreased water irrigation losses by deeppercolation, evaporation and run off by good land leveling with $0.1 \%$ slope, closed conduit to carry water to the field and good water distribution along the upper part of the field through gated pipe system. The results revealed that irrigation with gated pipe improved yield WUE for sugarcane crop under three treatments furrows lengths compared to traditional irrigation.

\section{REFERENCES}

Abd EI-Motaleb, I. A. M. A. EI-Saadawy, F. 1. Hindy, M. A. Mattar (2006). Hydraulic analysis of telescopic perforated pipes for surface irrigation system. The 14th. Annual Conference of the Misr Society, Agric. Eng. 22 Nov. 2006, pp. (1090-1132).

Abo-soliman M. S. M., H. E. Osman, M. M. Saied and E. H. Omar (2005), Maize, barley production and water use efficiency as influenced by different irrigation methods in Egyption old land $.13^{\text {th }}$ Ann. Conf. of Misr Soc. Agric. Eng., 14-15 Dec,: 1-22. 
Black, C. A., D. D. Evans, L. E. Ensminger, and R. C. Dinauer, (1965): Methods of analysis (part 1). Am. Soc. of Agron., Inc. Publ. Madison, Wisc., U.S.A.

Cazanescu S., Mihai D., and Mudura R., (2010). Modern technology for land leveling, based on a 3d scanner. Rese. J. of Agric. Scie., 42 (3), p.: 471- 478.

Chu, S. T., (1984): Hydraulic of perforated irrigation trail tube. J of Irrig. And Drain. Eng. ASCE, 110 (1): 88 - 97.

El Awady, M.N., M.T. El Tantawy, S.S. Hassan and A.O.M. ElAshhab (2002). Water flow uniformity distribution through irrigation gated pipes. Misr. J. Agr. Eng. 19 (3) : p 677 - 690.

General Administration of Agricultural Economics (2004). "Agricultural economics, , Minstery of Agriculture, Egypt,57-69P.

Hassan, S. S. A., 1998: Engineering studies for increasing water distribution uniformity of perforated pipes for surface irrigation systems. Ph. D. Thesis, Agric. Eng. Dept., Fac. of Agric., Cairo Univ.

Hassan, S. S. A. (2004). Effect of border gated pipes technique on the water irrigation efficiency for wheat crop. Misr J. Agric. Eng-, 21 (I): $125-138$.

Israelson, O.W wad Hansen, V. F: (1962). Irrigation principles and practices. 3 Ed. John Wiley \& Sons. Inc. New York.

Jensen, M. E., 1980: Design and operating of farm irrigation system ASAE, Monograph 3, ASAE, St. Joseph, MI, 829 pp.

Jensen, M. E., 1983: Design and operating of farm irrigation system Trans. of the ASAE, chapter 17, pp 721-724.

Kincaid, D. C. and W. D. Kemper, 1982: Cablegation : 11. Simulation and design of the moving plug gated pipe irrigation system. Trans. of the ASAE $25: 388-395$.

Massey, B. S. (1990). Mechanics of fluid. Pub, by Van N-ostarnd, Reinhold (U.K) Co, - Ltd, Molly Millars Lane, Works, Berk, Engi. : 625 pp. (C. F. Hassan, 1990) 
Morcos, M. A.; A. F. El-Sahrigi; M. Hanafy and S. S. Hassan, 1994: A mathematical approach to predict the pressure head inside the perforated tubes. Misr J. Agric. Eng. 11(4):1041-1065.

Naresh R. K., Singh S. P., Misra A. K., Tomar S. S., Kumar P., Kumar V., and Kumar S., (2014). Evaluation of the laser leveled land leveling technology on crop yield and water use productivity in Western Uttar Pradesh. Afr. J. Agric. Res. p.:473-478.

Sonbol H.A., El-Hadidi, E. M., Saied, M. M. and Aiad M. A. El-F., 2007. Effect of surface irrigation methods and land leveling on salt distribution and moisture uptake by cotton plant in salt affected soils at North Delta. Mansoura J. of Agric.Sci. - M. Uni. Vol. 32, No. 9, P.7999- 8015.

Sugar Crops Council, 1996. "Annual report of sugar crops in Egypt." Ministry of Agriculture, Cairo, Egypt, 25P.

Wu, I. P. and H. M. Gitlin, 1983: Sprinkler irrigation for uniformity on slopes. Trans. Of the ASAE, 26: 1698-1703.

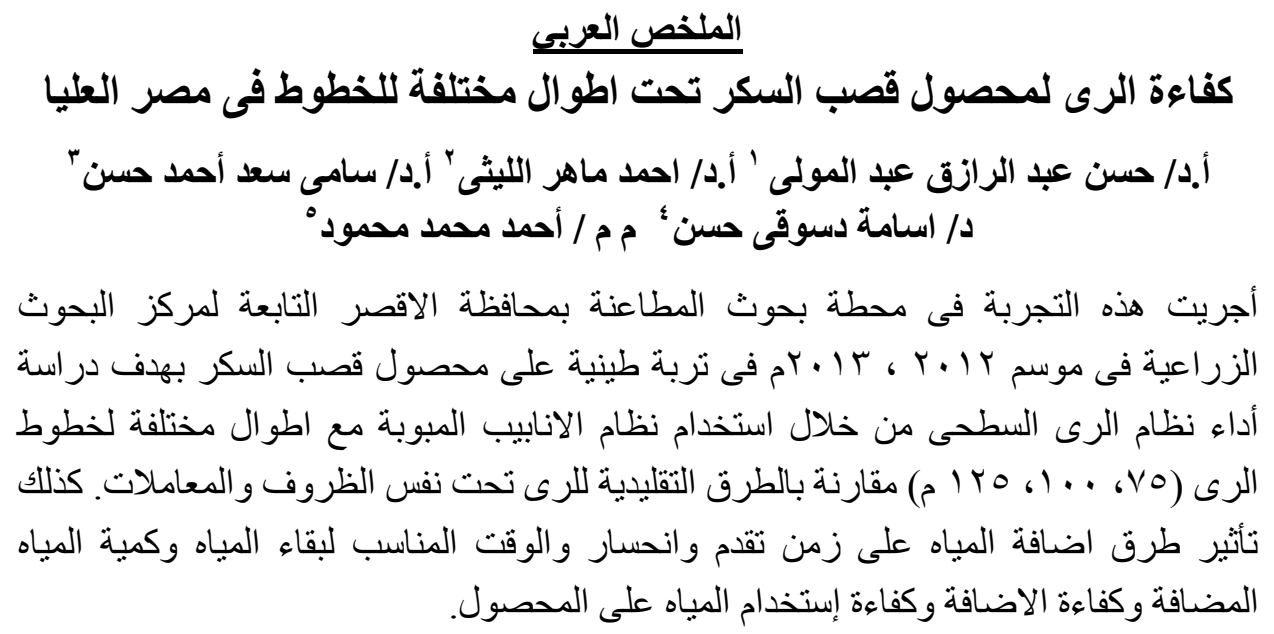

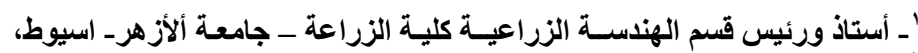

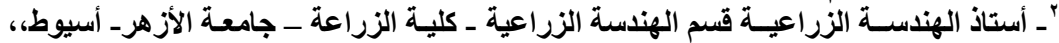

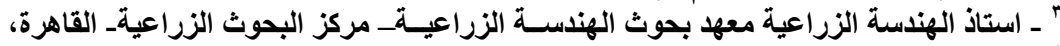

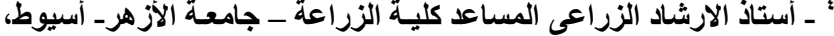

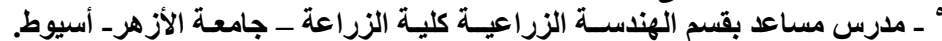

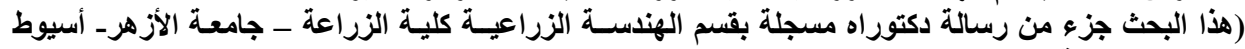
تحت إشراف لجنة الإشراف المشار إليها سابقا) ـ 


\section{واضحت النتائج مايلإ}

ا - يوجد اختلاف طفيف بين التصرفات المقاصة و الموصى بها بمقدار r +. . \% م وماتل

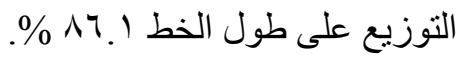

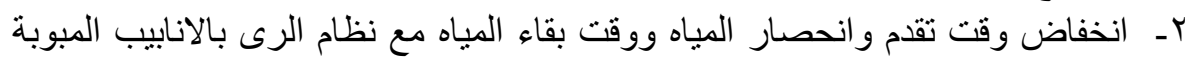

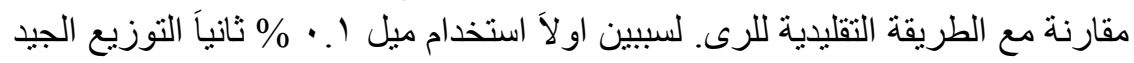
لمياه الرى بواسطة نظام الرى بالأنابيب المبوبة.

بـ انخفضت كمية المياه المضافة عن طريق الرى بالانابيب المبوبة T2 بنسبة (46.14، باهنة

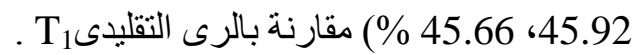

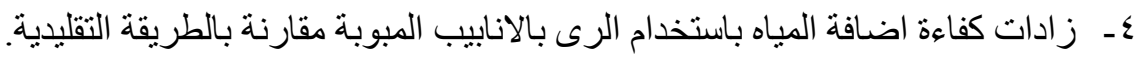
ــ زدات كفاءة التوزيع بزيادات قليلة بين الرى بالانابيب المبوبة و الطريقة التقليدية. 7- زادت انتاجية الفدان من خلال استخدام الانابيب المبوبة بمقدار (

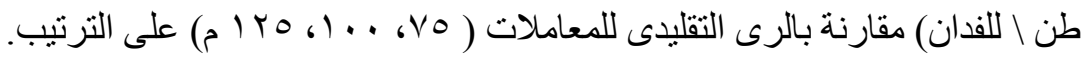

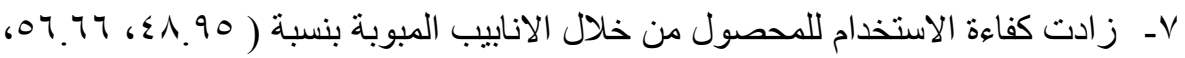

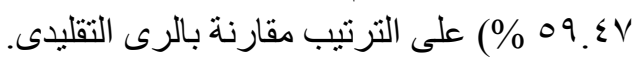

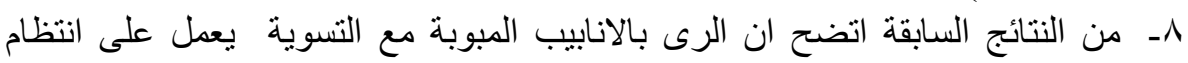

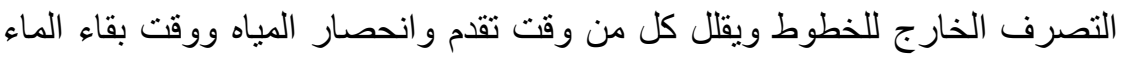
وكمية المياه المضافة، وزيادة المحصول وكفاءة الاضافة وكفاءة الاستخدام للمحصول. 